\title{
Re-reading the SARS-COV-2 Epidemic in Bergamo
}

\author{
Daniele Schena ${ }^{1} \cdot$ Guido Marinoni ${ }^{2} \cdot$ Luca Galassi $^{1}$ (D)
}

Accepted: 21 July 2020 / Published online: 11 August 2020

(C) Springer Nature Switzerland AG 2020

\begin{abstract}
Bergamo province was one of the hardest hit regions by the novel SARS-CoV-2 virus. Since the beginning of the epidemic, more than 30,000 people have died as a result of the infection. Although many hypotheses have been formulated to explain the rapid outbreak of COVID-19 in Lombardy, none have yet considered the specific conditions that characterized the Bergamo hinterland. In this letter, we try to identify and investigate which elements could have helped the rapid spreading of the virus.
\end{abstract}

Keywords COVID-19 $\cdot$ Italian SARS-CoV-2 epidemic $\cdot$ Coronavirus

In recent months, several hypotheses have been offered to explain the rapid spread of the virus in Bergamo province and Lombardy, but all of them are focused on what happened in the hospitals (Codogno, Alzano Lombardo, and other emergency departments across the territory) involved in the SARSCoV-2 epidemic.

In particular, the management of two patients admitted in the Alzano Lombardo Hospital on the 23rd of February was thought to be critical for the epidemic outbreak.

However, we believe this conclusion to be imprecise because it does not consider at all the context outside the hospitals.

New evidence shows how the virus was already in Italy from mid-January [1]. This belief is strengthened by the fact that some physicians had positive swab test results on the 25th of February, and it is reasonable to think that the contagion happened days before the test.

Moreover, it also has to be considered that COVID-19 presented itself, at first, to be an asymptomatic virus making it extremely difficult to identify any suspect cases prior to the appearance of symptoms.

This article is part of the Topical Collection on Covid-19

Luca Galassi

lucagalassimd@gmail.com

1 ASST Bergamo Est, P.O. Pesenti Fenaroli, Orthopedics and Traumatology Unit, Via G. Mazzini 88, 24022, Alzano Lombardo, Bergamo, Italy

2 Bergamo Medical Council, Via Giacomo Manzu', 25, 24122 Bergamo, Italy
During the last week of February and first week of March, many events could be implied in the spread of SARS-CoV-2. The ongoing trade between factories around Bergamo (involving 4000 workers) and different regions of China was maintained until the beginning of the Province lock down on the 8th of March. Moreover, as reported in the official communication to the government by Lombardy Medical Council [2], general practitioners lack of individual protection devices during their routine activity could have further eased the SarsCoV2 spreading in the population. An important role might also be attributed to a soccer match that took place on 19th of February in Milan with an audience of more than 40,000 people (the majority coming from the Bergamo hinterland).

It is also important to point out that the criteria for oropharyngeal swab tests imposed by the Italian Health Ministry suggested that tests should only be administered in cases of reasonable suspicion or for people coming into contact with people arriving from China.

We strongly support that no actual delay has taken place during the management of the two Covid-19 cases, but the smart intuition to test the patients, derived from government indications [3], could have helped to make clear the presence of an already ongoing epidemic.

Although no interstitial pneumonitis registry of the past years is present, more retrospective studies are needed to investigate among all the hospital facilities in Bergamo and surrounding areas in order to clarify the real evolution of Covid-19 in the province of Bergamo.

In conclusion, and for future reference, it is vital to organize a stronger collaboration between regional medical centers and hospitals in order to coordinate all the efforts to combat the spreading of the virus. 
Authors' Contributions All authors conceived and planned this paper, devised the project and the main conceptual ideas. Moreover, all authors provided critical feedback and helped shape the research, analysis and writing of the manuscript.

\section{Compliance with Ethical Standards}

Conflict of Interest The authors certify that they have NO affiliations with or involvement in any organization or entity with any financial interest (such as honoraria; educational grants; participation in speakers' bureaus; membership, employment, consultancies, stock ownership, or other equity interest; and expert testimony or patent-licensing arrangements), or non-financial interest (such as personal or professional relationships, affiliations, knowledge, or beliefs) in the subject matter or materials discussed in this manuscript.

\section{References}

1. Zehender G, Lai A, Bergna A, Meroni L, Riva A, Balotta C, et al. Genomic characterization and phylogenetic analysis of SARS-COV2 in Italy. J Med Virol. 2020. https://doi.org/10.1002/jmv.25794.

2. FIMMG Federazione Italiana Medici di Famiglia . Misure cautelative relative all'evolversi della situazione epidemiologica da COVID-19. 2020. http://www.fimmg.org Accessed 27 May 2020.

3. Ministero della Salute. Aggiornamento della definizione di caso COVID19. 2020. https://www.who.int/emergencies/diseases/novelcoronavirus-2019/situation-reports/ Accessed 27 May 2020.

Publisher's Note Springer Nature remains neutral with regard to jurisdictional claims in published maps and institutional affiliations. 